\title{
XXXII. Observations on the dangerous rock usually called The Drunken Sailor, lying off the flag-staff point, Colombo, Island of Ceylon
}

\section{Lieut. Col. George Wright}

To cite this article: Lieut. Col. George Wright (1822) XXXII. Observations on the dangerous rock usually called The Drunken Sailor, lying off the flag-staff point, Colombo, Island of Ceylon, Philosophical Magazine Series 1, 59:286, 121-122, DOI: 10.1080/14786442208652699

To link to this article: http://dx.doi.org/10.1080/14786442208652699

电 Published online: 27 Jul 2009.

Submit your article to this journal $\pi$

Џll Article views: 2

Q View related articles $₫$ 
say, that M. Bessel does not use, or does not know how to use, his own tables.

'To be brief : 'The error of your correspondent has arisen from his supposing the increase or decrease of the differences to be regular, and calculating accordingly. If instead of taking a mean proportional part of the difference, he will find the true difference, by interpolation; for Dec. 14.56 he will get 0,026 , which subtracted from +0.273 , gives +0.217 , the very same $M$. Bessel has given in his example. If in the same way he will recalculate the "some hundreds of observations," which he tells us he has reduced, I have no doubt it will lead to a conclusion very different from that he has so rashly aropted. I will also hope that, calculating in this way, he will find that the tables do give the same corrections I have made use of.

$$
\text { I am, sir, your obedient servant, }
$$

James Grooby.

XXXII. Observations on the dangerous Rock usually called The Drunken Sailor, lying off the Flag-Staff Puint, Colombo, Island of Ceylon. By Lieut. Col. George Wright*.

$\mathbf{T}$

Tre above rock, usually called by the English The Drunken Sailor, and by the Dutch De Dronke Matroos, lies in a direction by compass about west-south-west from the Flag-staff of Colombo, and distant from a bold projecting rock usually named the Portuguese Rock, on the sea shore directly in front of the Flag-staff about three quarters of a mile. Its situation is in a most dangerous position, being exactly in the track that a ship would make in trying to reach the anchorage in the roads of Colombo during the north-east monsoon, and at which time it may be considered as most dangerous, from the circumstance of the sea not making any break upon it, which is the case during the south-west monsoon, when breakers are distinctly seen at intervals, and which in general sufficiently mark its position : but even then it is not always visible, as at times only a small white surge scarcely discernible can be perceived to rise over it once in seven or eight minutes.

Upon the summit of the rock the greatest depth of water which has as yet been ascertained, is about six feet; and the smallest about lhree feet and a half, that being the usual difference of the tides on this coast, or rather the difference of level in the sea caused more by strong southerly winds than by the tides, which at Colombo do not reach two feet. The summit of the rock is very small, and appears to be of an oval shape, of about twenty or thirty feet in circumference, and the sides

- From the Transactions of the Ceylon Literary Society.

Vol. 59. No. 286. Fel. 1822. 
of the rock exceedingly steep and abrupt ; the depth of water at a few yards distance, from nine feet to twenty-five; and a little further off to about nine fathom, which is the greatest depth of water between the rock and the shore; the rock itself appears to be of a sharp and hard kind, much indented, and full of crevices, as small anchors or grapplings which have been made use of by boats to anchor on it, as well as the leads used in sounding the depth, have in general been extricated therefrom with much difficulty; and from the circumstance of the rock not appearing to increase in magnitude, it is most probably not of the description of coral rock so frequent in the Indian sea.

Although alluded to and taken notice of in some old Dutch manuscript charts and surveys, this rock appears to be but very little known in general, and few, if any, of the English charts take notice of it at all. One of the latest editions of that valuable work of Captain Horsburg, Hydrographer to the Honourable East India Company, mentions it; but as the same is contained in an appendix to the second volume of the work, the circumstance there is no doubt often escapes observations. A transport with troops making the roads of Colombo in the year 1819, passed within a short distance of it, not aware of the danger; and some years since a large and valuable East Indiaman stood close in shore and tacked several times close to it, and passed between it and the shore without being aware that such a rock existed.

Colombo, Aug. 8, 1821.

XXXIII. Account of an improved Method of planting Vines for Forcing. By Mr. DANIEL JUDd, F.H.S.*

$\mathbf{H}_{\mathrm{H}}$ FREWITH I send an account of my management of the vines in the garden of Charles Campbell, Esq. of Edmonton, of which I have the charge.

My compost was formed as follows: In the winter of 1817, I procured a quantity of the top-spit of soil from a common in the neighbourhood, which consisted of a rich loam, rather inclining to be gritty, which property I prefer, because it gives a porousness to the compost, thereby allowing the water to pass freely through it. At the same time I collected some lime rubbish, well broken to pieces and sifted, some old tan, some leaf mould, and a quantity of the richest old dung I could select from the forcing-beds and elsewhere.

These materials having been kept separate, and frequently turned over in the summer, were nixed together in the autumn

* From the Transactions of the London Horticultural Socicty. 